\title{
Innovative Design and Fabrication of a Two-Dimensional Model in Solid Oxide Fuel Cell Stack
}

\author{
Xuan-Vien Nguyen ${ }^{1, *}$, Guo-Bin Jung ${ }^{2}$, Shih-Hung Chan ${ }^{2}$ \\ ${ }^{1}$ Department of Thermal Engineering, Ho Chi Minh City University of Technology and Education, Ho \\ Chi Minh City, Viet Nam; \\ ${ }^{2}$ Department of Mechanical Engineering \& Fuel Cell Center, Yuan Ze University, Taoyuan 320, \\ Taiwan; \\ *E-mail: wienheating@gmail.com, viennx@hcmute.edu.vn (XuanVien-Nguyen).
}

doi: $10.20964 / 2019.09 .58$

Received: 10 April 2019 / Accepted: 9 July 2019 / Published: 5 August 2019

\begin{abstract}
In this study, an innovative two-dimensional solid oxide fuel cell (SOFC) stack based on a horizontal structure was developed. Planar anode-supported cells were utilized and integrated into a twodimensional SOFC stack. The stack was designed to be operated in parallel as a large single cell and in series as a stack. The stack consisted of fuel and oxidant chambers, which allowed good heat transfer for preheating of the fuel inlet. These chambers inhibited the cooling effect of fuel (and oxidant) and thus improved the cell performance. Additionally, the two-dimensional SOFC stack model was designed for the perpendicular flows of fuel (and oxidant) directed to the electrode surfaces of the cells. This ensured the effective diffusion of fuel and oxidant between the anode and cathode surfaces, respectively. When the cells were connected in parallel, the two-dimensional stack functioned as a large single cell that generates a high current. When the cells were connected in series, the stack generated a high voltage. This innovative two-dimensional SOFC stack thus functioned as a large single cell and as a stack.
\end{abstract}

Keywords: Solid oxide fuel cell; Planar solid oxide fuel cell stack; Anode chamber; Cathode chamber.; SOFC cooling effect; Preheating

\section{FULL TEXT}

(C) 2019 The Authors. Published by ESG (www.electrochemsci.org). This article is an open access article distributed under the terms and conditions of the Creative Commons Attribution license (http://creativecommons.org/licenses/by/4.0/). 